Counsellia: Jurnal Bimbingan dan Konseling, 10 (1), $2020 \mid 69-82$

Copyright $(2020$ Universitas PGRI Madiun

ISSN: 2088-3072 (Print) / 2477-5886 (Online)

Available online at: http://e-journal.unipma.ac.id/index.php/JBK

DOI: 10.25273/counsellia.v10i1.6214

\title{
Peer Guidance: development of Children's Wellbeing on Addicted Parents
}

\author{
Agus Supriyanto ${ }^{1}$, Nurlita Hendiani ${ }^{2}$, Amien Wahyudi ${ }^{3}$, Purwadi ${ }^{4}$, Mufied Fauziah ${ }^{5}$ \\ ${ }^{1}$ Fakultas Keguruan dan Ilmu Pendidikan, Universitas Ahmad Dahlan, Yogyakarta \\ agus.supriyanto@bk.uad.ac.id \\ ${ }^{2}$ Badan Besar Rehabilitasi Narkoba, Bogor \\ nurlitahendiani@bnn.go.id \\ ${ }^{3}$ Fakultas Keguruan dan Ilmu Pendidikan, Universitas Ahmad Dahlan, Yogyakarta \\ amien.wahyudi@bk.uad.ac.id, \\ ${ }^{4}$ Fakultas Keguruan dan Ilmu Pendidikan, Universitas Ahmad Dahlan, Yogyakarta \\ purwadi@psy.uad.ac.id, \\ ${ }^{5}$ Fakultas Keguruan dan Ilmu Pendidikan, Universitas Ahmad Dahlan, Yogyakarta \\ mufied.fauziah@bk.uad.ac.id
}

\begin{abstract}
Children are victims of parents who are undergoing drug rehabilitation programs. The factor is that parents do not accompany the education process for a specified period. Peer approaches by school counselors play a significant role in developing children's welfare in school. The goals of this study were to determine the application of peer guidelines for the development of healthy children of addicted parents. This research uses a literature study and a case study method. The data used in the study originated from the literature, as well as the primary references and interviews. Interviews conducted to parents of drug users in the large centers of drug rehabilitation. The analysis used in the descriptive study of literature method and case study method study. The findings conclude that the welfare of children from drug abuser's parents causes stress in children to influence the psychological, social, and academic dimensions. Peer guidance applications provide support for the education of children from parents who are undergoing drug rehabilitation programs and success in school. Peer skills implement openness, asking questions, and reflection, and empathy. The impact is child welfare in the psychological, social, and academic dimensions. Collaboration between addicted counselors, school counselors, parents, and guardians is needed.
\end{abstract}

Keywords: peer guidance, child well-being, drug

\section{INTRODUCTION}

Problems with children's mental health have an impact on maladaptive behavior (Avenevoli et al., 2013). Parents, as drug users, tend to abuse children and have an effect on children's mental health. One of the problems is drugs. Drugs are toxins in the human body and cause damage to the human body system. Drugs affect the life of the country. The use of drugs in medicine must be proven safe, adequate, and well-controlled (Strom \& Melmon, 2019).

Some facts about drug abuse into drugs have a terrible impact on life. The facts reveal that drugs that are misused side effects and dangerous to humans, and also have a 
high risk to the pharmaceutical world (Zhao et al., 2019). The facts in the Philippines about anti-drug campaigns to eliminate drugs in this country have resulted in a rapid increase in the number of deaths (Bautista, 2017). The dangers of drugs also cause diseases in the human body or exacerbate existing conditions. Mental illness is what is often experienced by drug users (Lowe et al., 2019). Mental illness affects the child's parenting and self-development of drug users. Then followed by stress and anxiety which can have an impact on the likelihood of suicide (Coates et al., 2019).

Problematic alcohol use, according to criteria, indicated that $67.4 \%$ used alcohol, while $46.0 \%$ met the criteria for problematic drug use (Sinadinovic et al., 2010). Victims of drug abusers from parents are children. Children experience psychological, physical, and social problems. The results revealed that $8 \%$ of children reported physical abuse that occurred in childhood and resulted in the appearance of attention-deficit hyperactivity disorder, post-traumatic stress disorder, and bipolar disorder (Sugaya et al., 2012). Problems psychotic disorders cause a variety of loads; one of them is psychological stress (distress), to the problem of a social stigma (Subandi, 2014). Children's substance abuse tends to mental disorders in children's education. Parents with good well-being have an impact on the child's low problem behavior (Sumargi \& Kristi, 2017).

The absence of an element of father or mother as the primary learner in a child's life has an influence on psychological conditions, one of which is the welfare of the child. The absence of an element of father or mother because one of them is undergoing a drug rehabilitation program. The impact of all these things is psychological, social, and academic development. Child emotional and social development can be understanding as a crisis in child development as the learning process in a family environment (Nurmalitasari, 2015).

Parent neglect of a child undergoing drug rehabilitation is a significant factor in child well-being and child achievement from a psychological dimension-counselors as role models for children to prevent negative behavior. Family relationships lead to welfare in children and lead to better child outcomes (Pruett et al., 2019). The welfare of the child is a life order and life of the child that can guarantee the child's growth and development naturally, both psychologically, physically, and socially. Collaboration counselor with parents and parental involvement in education also has a positive correlation with student involvement in school (Kristiyani, 2013; Supriyanto, 2016a) with interventions that focus on child welfare (Jonson-Reid \& Chiang, 2019).

Parents, school counselors, and substance abuse counselors are having the ability and commitments for the prevention and development of child well-being for addicted parents. Family-based models are not only a viable treatment alternative for the treatment of drug abuse but are now consistently recognized among the most effective approaches for treating both adults and adolescents with drug problems (Rowe, 2012). Parents have an essential role in developing children's competencies because parents become the primary and first educators for children (Supriyanto, 2016b). Families of addicts contribute to the development of the child. In addition to the family, school counselors also provide to the prevention of child on negative behavior through peer guidance.

Peer guidance is a guidance process that involves other students as friends through the training process provided by school counselors. Peer-based strategies have benefits for children's well-being (Matz-Costa et al., 2019). Peers can provide support to be able to improve social abilities and psychological development, especially in children who have low welfare due to parents who are undergoing drug rehabilitation. Peer support has a positive impact on children's school experience and well-being and can function as an intervention and prevention of school bullying (Tzani-Pepelasi et al., 2019). The meaning is peer guidance is the right strategy used by school counselors to improve the welfare of 
children through peers. The intervention of counselors through a parent in behaviormanagement, child social cognitive skills, reading, home visiting, mentoring, and classroom curricula (Group, 2011).

Intervention by peer guidance undertaken to reduce maladaptive behavior and be aware of trafficking and drug abuse - one of the responses through peer guidance. Peer guidance is also a strategy that might be appropriate also if peers have peer guidance skills. In addition to guidance, school counselors have counseling abilities. Those problems resolved through a campaign against drug abuse and effective counseling programs (Oluremi Fareo, 2012). Behavior counseling interventions with multiple contacts can reduce drug use behavior (Jonas et al., 2012; Moyer, 2013).

This article discusses the welfare conditions of children with parents who undergo drug rehabilitation programs. Then this article discusses the strategy of peer guidance as an intervention from school counselors with skills that bind to peer guidance. The skills of peer guidance can apply to school counselors and peers for the development of the child's welfare.

\section{RESEARCH METHOD}

This research uses a case study and a literature study method. This research is to reveal effective theories about the peer guidance approach in school for developing child well-being on parent drug abusers. The literature study to construct the theoretical concepts of peer guidance skills that implementation in guidance and counseling services. The case study to find out the dimensions of child welfare development on addicted parents. The objective of the research is to establish the theoretical concepts and practice of peer guidance as an effort to developing child well-being on parent drug abusers to help the government to build a drug-free society. The theoretical concepts of peer guidance used by school counselors and drug abuse counselors. Peer guidance as one way for the developing child's well-being of addicted parents.

The data used in the study originated from the literature, as well as the primary references and interviews. Interviews conducted to parents of drug users in the large centers of drug rehabilitation, Bogor, Indonesia. The analysis used in the descriptive study of literature method and case study method study in three ways: (1) inventory of kinds of literature and interviews, (2) description of types of research and interviews, and (3) comparison of essay to developing child well-being on parents drug abusers. The documentation and recommendations are valid and used in this research in the form of journals, books, scientific studies, and research results. Many kinds of the journal, papers, scientific studies, and research results used in this research. Literature review and reference in the content analysis, so that emphasizes the analysis or interpretation of written materials based on the context.

Interviews applicated with children or families of children left behind by fathers or mothers who treated in the Drug Rehabilitation Program, Lido Bogor, Indonesia Country. The number of children and families interviewed is six participants. Interviews using mobile media by counselors as research partners. The interviewee details are as follows.

Table 1. Interview Participants

\begin{tabular}{ccccc}
\hline No & $\begin{array}{c}\text { Parents } \\
\text { (Initial Name) }\end{array}$ & $\begin{array}{c}\text { Male/ } \\
\text { Female }\end{array}$ & Parent Education & $\begin{array}{c}\text { Condition of Children as the } \\
\text { Main Subject of the Interview }\end{array}$ \\
\hline 1 & ZZ & Male & Senior High School & At school \\
\hline 2 & IMM & Male & $\begin{array}{c}\text { Middle School (High School } \\
\text { Only until grade 1) }\end{array}$ & At school \\
\hline 3 & MR & Male & Vocational School & At school \\
\hline 4 & MP & Female & High School C Package & At school \\
\hline
\end{tabular}




\begin{tabular}{ccccc}
\hline No & $\begin{array}{c}\text { Parents } \\
\text { (Initial Name) }\end{array}$ & $\begin{array}{c}\text { Male/ } \\
\text { Female }\end{array}$ & Parent Education & $\begin{array}{c}\text { Condition of Children as the } \\
\text { Main Subject of the Interview }\end{array}$ \\
\hline 5 & MUN & Female & $\begin{array}{c}\text { Middle School (High } \\
\text { School Drop Out) }\end{array}$ & At school \\
\hline 6 & A & Female & $\begin{array}{c}\text { Middle School (High } \\
\text { School Drop Out) }\end{array}$ & At school \\
\hline
\end{tabular}

Descriptive data analysis used to analyze the results of interviews with children/families of children and study literature to develop peer guidance skills. The process of data analysis used three stages, namely data reduction, data presentation, and conclusion. This study directly displays data conclusions.

\section{RESULT AND DISCUSSION \\ Result}

Preliminary data get information on children and families from drug addicts that most children live with broken home conditions and a small proportion with harmonious families. Some children have felt beaten by a parent, one child is broken, and one child feels pampered, two children are less able to socialize. Of the six facts, it remains revealed that every child has a deficiency or problem. The impact is the welfare of children in table 3 .

Table 2. Cases Experienced by Children of Parents of Drug Abusers

\begin{tabular}{|c|c|c|c|}
\hline No & Child & Initial Information & Childs Case in School \\
\hline 1 & Child of ZZ & $\begin{array}{l}\text { Often bickering, having } \\
\text { been beaten by parents in } \\
\text { middle school. }\end{array}$ & $\begin{array}{l}\text { 1. Students are suspect it can committing } \\
\text { crimes against their friends because they } \\
\text { have parents as drug addicts. } \\
\text { 2. Suspicion of social conditions affects } \\
\text { students' uncomfortable feelings about } \\
\text { school life. } \\
\text { 3. Negative stamp from the school. } \\
\text { 4. Feeling uncomfortable with school } \\
\text { conditions. }\end{array}$ \\
\hline 2 & $\begin{array}{l}\text { Child of } \\
\text { IMM }\end{array}$ & $\begin{array}{l}\text { He was having a } \\
\text { harmonious family and three } \\
\text { brothers. The child was } \\
\text { beating when he was in } \\
\text { middle school because he } \\
\text { didn't go home and resulting } \\
\text { in trauma. }\end{array}$ & $\begin{array}{l}\text { 1. Students lack the supervision of the } \\
\text { family. } \\
\text { 2. Having fear because of a lack of trust by } \\
\text { others. } \\
\text { 3. Less accepted or shunned by friends } \\
\text { because they have a father as a drug } \\
\text { addict. } \\
\text { 4. Feeling uncomfortable because parents } \\
\text { do not trust it with himself }\end{array}$ \\
\hline 3 & Child of MR & $\begin{array}{l}\text { It has limitations for } \\
\text { challenging to communicate } \\
\text { with others due to a lack of } \\
\text { development. }\end{array}$ & $\begin{array}{l}\text { 1. Peers or others don't accept me because } \\
\text { of viewing parents. } \\
\text { 2. Fear of peers if something is missing. } \\
\text { 3. Having limitations in communicating } \\
\text { with friends or other people because } \\
\text { friends shun them. } \\
\text { 4. Negative perspectives from other people } \\
\text { about me. }\end{array}$ \\
\hline 4 & Child of MP & $\begin{array}{l}\text { Mother single parent } \\
\text { because father died. Mothers } \\
\text { used to be harmonious, but } \\
\text { with work problems, it has } \\
\text { an impact on children's well- } \\
\text { being. }\end{array}$ & $\begin{array}{l}\text { 1. Not trusted by friends because of } \\
\text { negative perspectives about parents as } \\
\text { drug users. } \\
\text { 2. Having the burden always to send the } \\
\text { needs of parents at the rehabilitation } \\
\text { site, so that I,m work to support my } \\
\text { parents. }\end{array}$ \\
\hline
\end{tabular}




\begin{tabular}{|c|c|c|c|}
\hline No & Child & Initial Information & Childs Case in School \\
\hline 5 & $\begin{array}{l}\text { Child of } \\
\text { MUN }\end{array}$ & $\begin{array}{l}\text { I have broken home family. } \\
\text { Beginning to live with a } \\
\text { grandmother, after junior } \\
\text { high school, she joined my } \\
\text { mother and stepfather. The } \\
\text { biological father is different } \\
\text { from the city and has never } \\
\text { been responsible }\end{array}$ & $\begin{array}{l}\text { 1. Distrust from my relatives, friends, } \\
\text { neighbors, or the community around me, } \\
\text { because my mother is a drug addict } \\
\text { undergoing rehabilitation. } \\
\text { 2. The existence of a negative stamp from } \\
\text { the district. } \\
\text { 3. Feel pitied by other people. }\end{array}$ \\
\hline 6 & Child of A & $\begin{array}{l}\text { Too spoiled. Fathers are } \\
\text { firmer than mothers, before } \\
\text { using socializing with } \\
\text { friends and neighbors. }\end{array}$ & $\begin{array}{l}\text { 1. The distrust of the extended family for } \\
\text { fear of misusing their beliefs. } \\
\text { 2. Negative stamp from the community } \\
\text { and peers. } \\
\text { 3. Feelings of not being able to socialize } \\
\text { with other friends. }\end{array}$ \\
\hline
\end{tabular}

The results of the analysis revealed that every child of a drug addict parent had problems with social conditions. The most important thing is the distrust of the community, family, friends, and the environment. This distrust creates a negative stamp or stigma from within the child. This condition affects the psychological and social dimensions. The impact of psychological and social aspects has a tendency on children's academics in school.

The results found facts about children or adolescents who were abandoned by parents because of undergoing drug rehabilitation programs as drug users. Findings from the interviews show the data that the children's well-being of drug users who are undergoing drug rehab in neglect condition. Children or adolescents are vulnerable to problems from psychological, social, and academic. The first issues about psychological dimension takes the form of mental health conditions by cognitive, affective, and active dimensions of the child are applied in the child's life. The second issues about social aspect of the child shaped the anxiety of children in the association of children. The last issues parent involvement can correlated academic dimension and child's successed.

Table 3. The Conclusion Case Study to Wellbeing of Children with Parents of Drug Abuser in Drug Rehabilitation

\begin{tabular}{|c|c|c|c|}
\hline No & Aspect & Results & The Conclusion \\
\hline 1 & $\begin{array}{l}\text { Psychological } \\
\text { Dimensions }\end{array}$ & $\begin{array}{l}\text { Cognitive, Affective, } \\
\text { and Active }\end{array}$ & $\begin{array}{l}\text { The child thinks that he is } \\
\text { abandoned and has no attention } \\
\text { from the parents }\end{array}$ \\
\hline 2 & $\begin{array}{l}\text { Social } \\
\text { Dimensions }\end{array}$ & $\begin{array}{l}\text { Feelings of } \\
\text { and Fear of } \\
\text { People }\end{array}$ & $\begin{array}{l}\text { feelings of anxiety and fear of } \\
\text { meeting with the community }\end{array}$ \\
\hline 3 & $\begin{array}{l}\text { Academic } \\
\text { Dimensions }\end{array}$ & Parent Involvement & Child's successed di masa depan \\
\hline
\end{tabular}

Based on these facts, researchers need to formulate the right strategy, namely, peer guidance skills. School counselors and peers can implement peer guidance skills. Peers who have been trained by school counselors can apply peer guidance through the mentoring process. Assistance is carried out by the school counselor. Following is the design of peer guidance skills. 
Table 4. The Analysis Literature Study about Peer Guidance Skill

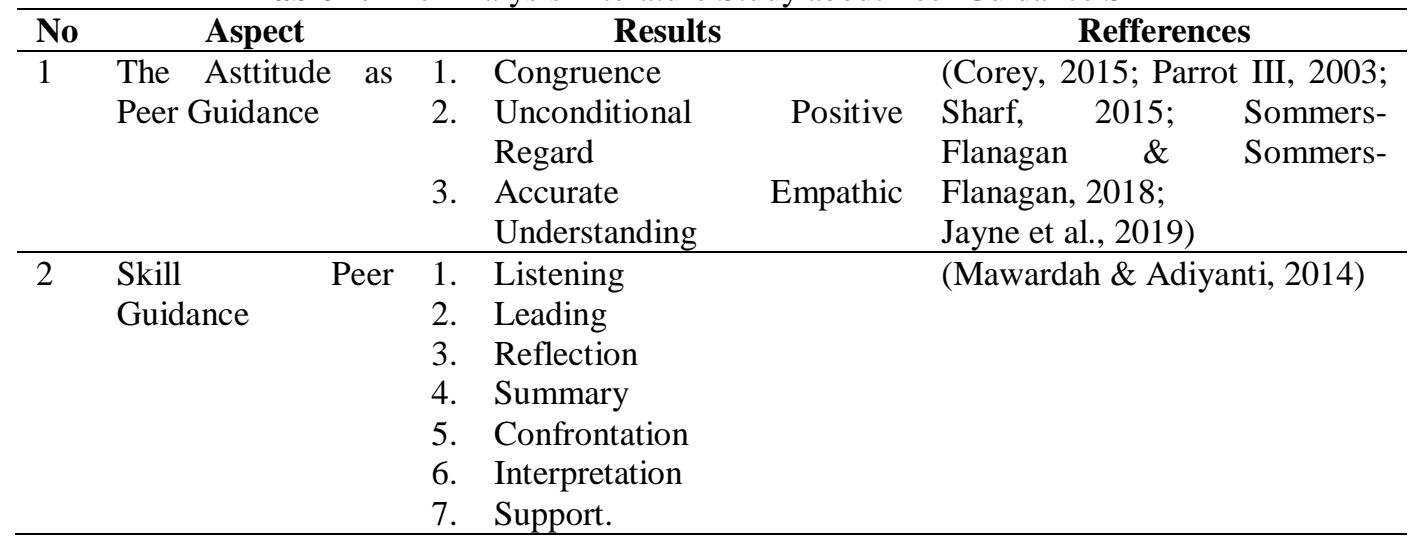

Peer guidance is the right strategy to increase the acceptance of children with parents of drug addicts. Peer guidance is carried out by peers of students with parents of drug addicts. The primary purpose of peer guidance is the development of children's wellbeing. The implementation of peer guidance requires assistance from the school counselor. Peers implementing peer guidance, need to have attitudes as peer members. That attitude is congruence, unconditional positive regard, and accurate empathic understanding.

In addition to attitude, peer as implementing peer guidance requires peer guidance skills. School counselors train seven skills in peer guidance. The seven skills are congruence, unconditional positive regard, and accurate empathic understanding applied through seven skills: listening, leading, reflection, summary, confrontation, interpretation, and support.

\section{Discussion}

\section{Child Well-Being on Parents Drug Abusers}

Child neglect affects children's well-being in three dimensions: psychological, social, and academic. Maladaptive behavior of children because of being abused or ignored before by parents and have an impact on adolescent development such as delinquency and substance abuse, romantic relationships, and sexuality (Trickett et al., 2011). Substance abuse and mental disorders of the mother can harm the development of children, especially the child's well-being related to emotional behavior and children's problems (Hser et al., 2015).

The children well-being with parents of drug users undergoing rehabilitation processes affects the child's psychological dimension. The psychological dimension takes the form of mental health conditions. The cognitive, affective, and active dimensions of the child are applied in the child's life. The child thinks that he is abandoned and has no attention from the parents. Children feel anxious about the perception of society. The child also has an aggressive behavioral tendency. Stress and verbal aggression on the individual and coping in the alleviation of stress, anger, and aggression, because stress causes strong negative emotions (Bodenmann et al., 2010). 


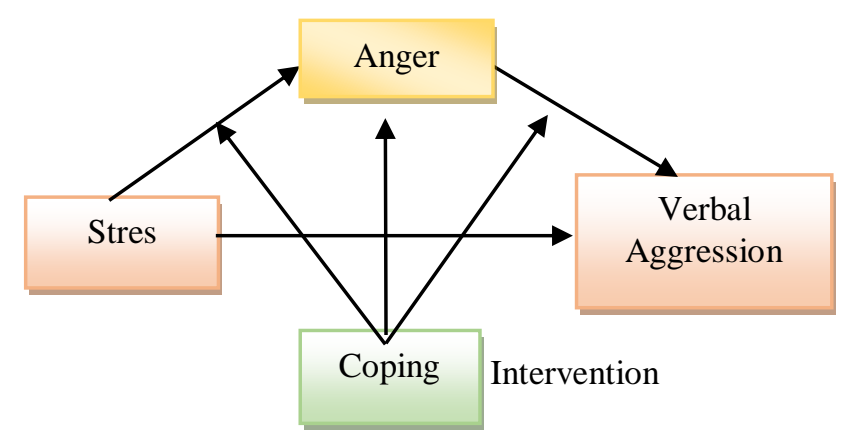

Figure 1. Stress, Anger, and Verbal Aggression in Intimate Relationships (Bodenmann et al., 2010)

The main discussion and fundamental basis of psychological problems of children with parents of drug addicts is the child's social condition. The wellbeing of children with parents of drug users undergoing rehabilitation also affects the social dimensions of children. Anxiety and fear in children because they are not accepted or negative stamp from the surrounding environment. The environment in question is the school environment, family environment, and the environment around the house. Negative stigma gives children the possibility to engage in maladaptive behavior because children need attention from others.

The social aspect of the child shaped the anxiety of children in the association of children. Children have feelings of anxiety and fear of meeting with the communityprevention for children through social guidance services for counselors. The provision of social services and parenting education can prevent the long-term impact of child abuse on substance use and related impairments (Nomura et al., 2012).

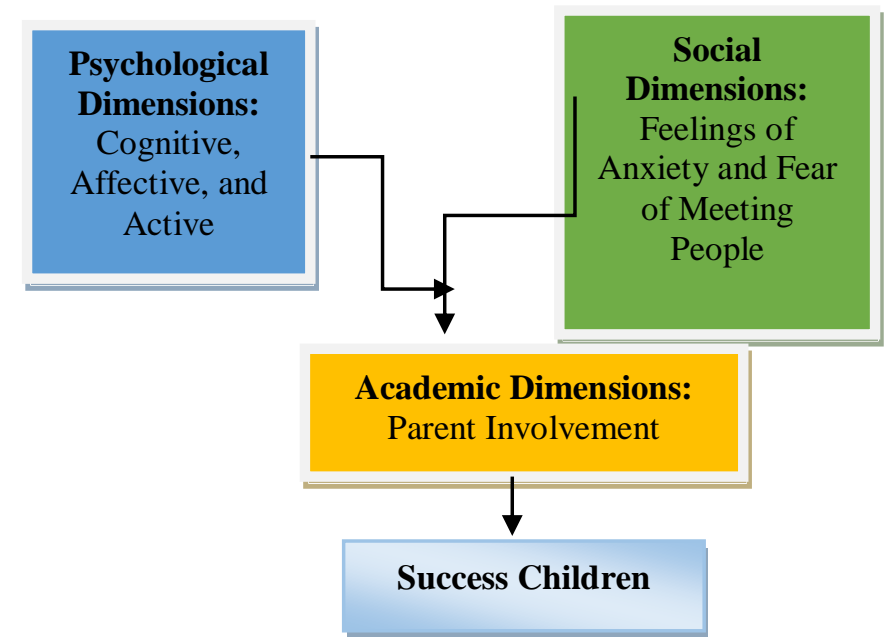

Figure 2. Dimensions of Child Well-Being

The final assumption is the child's academics in school. The impact of children left by parents due to undergoing drug rehabilitation programs is related to academics. This discuss also support by the research results that the absence of a parent role as a role model has an impact on the child's achievement. Parent involvement and family background affect academic performance (Muller, 2018). The intervention focuses on the importance of behavioral for school success, especially for children facing new risks (Sektnan et al., 2010). 


\section{Peer Guidance Approach in School for Developing Child Well-being on Parents Drug Abusers}

The development of child well-being affects children's education and achievement. Individuals form mental well-being, so they feel comfortable in their mindset and mental condition (Hartanto, 2017). The quality of care is an essential factor in the welfare of children from stress reactivity (Groeneveld et al., 2010). Alternative self-development of children through the role of society. Three alternative pathways have a goal as a framework for future research on the long-term effects of preventive parenting programs. The first through program effects on parenting skills, perceptions of parental efficacy, and reduction in barriers to effective parenting. The second through program-induced reductions in short-term problems of youth that persist over time, improvements in youth adaptation to stress, and increases in youth belief systems concerning the self and their relationships with others. The last through effects on contexts in which youth become involved and on youth-environment transactions (Sandler et al., 2011).

School counselors as mentors to children of victims of neglect. Who is it? Parents who are undergoing drug rehabilitation programs abandon children. The counselor needs to develop peer guidance skills on the student through peer on the victim. The fact that skills-based program to help prevent drug use rather than knowledge and affective (Faggiano et al., 2014). Peer guidance is effective in reducing alcohol abuse through specific skills training includes exercises using open-ended questions, ie, 77.3\%, Reflective listening exercises, that is $75 \%$, and role-playing $72.7 \%$. The information program included the content of alcohol and other drugs, ie, $86.4 \%$. Additional skills in the implementation of programs that motivational interviewing skills (Mastroleo et al., 2008).

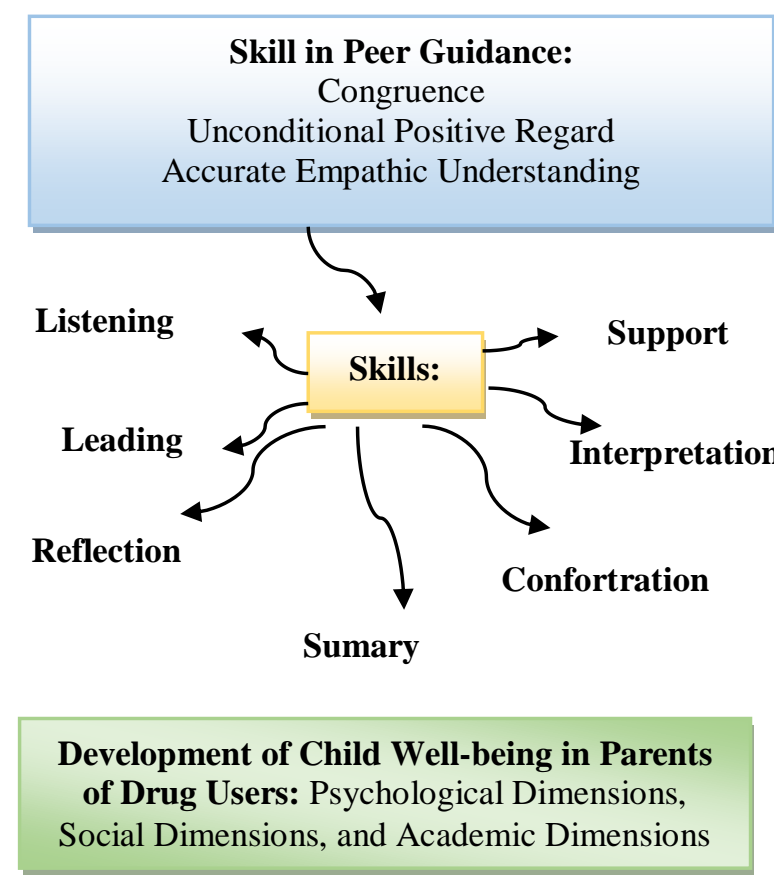

Figure 3. Peer Guidance Skills

Peer guidance skills implementation in discussion and daily life. Three necessary attitudes in understanding and helping peers; congruence, unconditional positive regard, and accurate empathic understanding (Corey, 2015; Jayne et al., 2019; Parrot III, 2003; Sharf, 2015; Sommers-Flanagan \& Sommers-Flanagan, 2018). Congruence, 
unconditional positive regard, and accurate empathic understanding implemented through seven skills: listening, leading, reflection, summary, confrontation, interpretation, and support. The powers of peer groups correlate with emotional regulation and their tendency to be cyberbullies (Mawardah \& Adiyanti, 2014).

Each peer member trained by the school counselor must have three attitudes in implementing peer guidance. The first attitude is the attitude of congruence. Peer members practice congruence through a process that is in harmony with what is carried out by peer members towards children who have parents of drug addicts. The purpose of congruence is so that children feel accepted and can actualize themselves. The alignment of values, beliefs, and behaviors is applying in the implementation of peer guidance (Robinson, 2019).

The other attitude is the attitude of positive things without conditions. A positive attitude without conditions is the attitude of a counselor or colleague towards students who ask for help without conditions and with a positive perspective. Unconditional positive regard is in line with the fact that students with drug addicts are labeled negatively by the Environment. Giving positive attention to clients has many benefits for students through verbal and nonverbal expression (Farber et al., 2018). An unconditional positive attitude is an essential favorable award from the peer guidance process for five forms of warmth that is not possessed by students, affirmation, support, self-esteem, and caring attitude (Farber \& Suzuki, 2018).

Another attitude as a member of peer guidance is the attitude of accurate empathic understanding. Accurate empathic understanding is an attitude to be able to understand and understand moods with conflicts that have (Lazarus et al., 2018). The attitude of empathy from school counselors and peer guidance members by naturally or expressively. Naturally, attitude usually is a habit of understanding for school counselors or peer guidance members without making it up. Empathy with expression adjusts to the client's condition. The implementation of empathy is a relatively reliable predictor of peer guidance by considering the considerable heterogeneity effect on each student (Elliott et al., 2018).

The implementation of three peer guidance attitudes needs to be supported by seven skills in peer guidance. The first skill is listening. Conceptually, human hearing varies, but as a school counselor and peer guidance, member listening is a challenge and requires more substantial involvement from spatial attention with selective attention (Alavash et al., 2019). The ability or listening skill is the main foundation to be able to understand the condition of students, especially students with parents of drug addicts with negative stigma from the community. Listening skills are not only conceptual but need training as a must-have skill for beginners (Yu et al., 2019).

The second skill is leading. School counselors or peer guidance members can lead group members and often become group leaders for peers in the peer guidance process. The ability as a group leader in the peer guidance process is the ability to direct group members to be able to accept friends whose parents are drug addicts. The leading ability of peers is unique. Usually, the leading ability is only owned by school counselors as guidance and counseling teachers (Cohen-Scali et al., 2018).

The third skill is reflection skills. The ability to reflect on peer guidance is to re-ask or summarize the results of a critical joint discussion with crucial thinking from counselors or peer guidance members. Reflections on the results of discussions or talks giving voluntarily and no coercion in guidance and counseling apply in collecting data (Ahmad et al., 2016). Data collection in question is gathering information that supports peer guidance. Peer guidance members have a critical reflection ability. Planning the 
reflection process needs to be careful because it is not only the ability to reflect on widely available speech but the need for concrete data (Slovák et al., 2017).

The fourth skill is summary skills. Skills summarize information during or part of the peer guidance process. This skill becomes essential because when school counselors or peer guidance members summarize information, peer guidance participants understand the contents of the peer guidance process. In contrast to the summary of the learning process. The summary is predetermined in the form of an appropriate sentence into a review taking into account the context. (Cao et al., 2015).

The fifth skill is confrontation skills. Conformation skills are skills that are used by school counselors or peer guidance members to show gaps, discrepancies, or increments from client words or information and then feedback through questions or statements to peer guidance groups. Input during the confrontation is different from the feedback if the opinion is agreed or the same. Input in the form of questions or statements when implementing the implementation of confrontational skills is because the information obtained is doubtful or unacceptable to the group in peer guidance. Confrontation in peer guidance is different from counseling. Confrontation in peer guidance to accept existing conditions. While confrontation in the counseling as a dialogue activity that resolved interactively (Strong \& Zeman, 2010).

The sixth skill is interpretation skills. Interpretation skills are the process of interpreting and providing views to clients about various kinds of behavior, events, or ideas that will apply or present a possible explanation of the response. This interpretation becomes unique when the school counselor or peer guidance member gives a view so that the picture can be accepted or rejected by the client. In the peer guidance process, interpretation is to strengthen the foundation of the results of the discussion and obtain future views. In contrast to the learning process, the description becomes a strong foundation from conceptualization (Grove et al., 2019).

The last skill in peer guidance is support skills. The support given to students with parents as drug addicts is essential. Supporting skills for academic development, accepting social conditions, and recovery of psychological conditions. Support skills are the expertise possessed in peer guidance. Support skills are the recognition of values in the form of support from peers in overcoming concerns (Davidson et al., 2012).

The listening skill consists of three stages, including receiving messages, processing messages, and sending messages. The inference skills reveal some words or talks for some time (Cormier et al., 2008). The skills guide aims to encourage the counselee to open communication, while a reflection has three areas: feelings, experiences, and context (Brammer \& Karkia, 1993). Confrontation is a skill to explain the gaps, conflicts, and discrepancies of messages between emotions, thoughts, and actions, while interpretation as a response that requires understanding and the ability to communicate the meaning of the message counselee (Cormier et al., 2008). Support is a condition where the counselee feels safe and comfortable psychologically (Brammer \& Karkia, 1993). Peer guidance skills implementation in counselors and peers for the development of child welfare in three dimensions: psychological, social, and academic.

\section{CONCLUSION}

The children's well-being of drug users who are undergoing drug rehab in neglect condition with three dimensions. The psychological aspect takes the form of mental health conditions. The cognitive, affective, and active dimensions of the child can influence implementation in the child's life. The development of child well-being affects children's education and achievement- alternative self-development of children through community roles, school counselors, and counselors' addiction. Counselors need to 
develop peer guidance skills on students through peers or victims in the practice of daily life skills. Three necessary attitudes in understanding and helping peers to develop the children's well-being through peer. Congruence, unconditional positive regard, and accurate empathic understanding implemented through seven skills: listening, leading, reflection, summary, confrontation, interpretation, and support.

\section{ACKNOWLEDGEMENT}

Thank you to the Research and Community Service Institute of Ahmad Dahlan University and the Head of the Lido Bogor Drug Rehabilitation Center for giving the Ahmad Dahlan University research team and the National Narcotics Research Team a chance. Thank you also to the family of drug users and parents/drug users in the interview process with the research team. The results of research related to peer guidance skills can apply to addiction counselors, school counselors, children, and parents who undergo drug rehabilitation programs.

\section{REFERENCES}

Ahmad, A., Ahmad, N., Bistamam, M. N., Razali, M. M. S. M., Yatim, A. A. M., Mukhti, T., \& Teck, W. K. (2016). The usage of counselling skills to increase motivation in teaching among trainee teachers in Malaysia. International Journal of Learning, Teaching and Educational Research, 15(13), 34-42.

Alavash, M., Tune, S., \& Obleser, J. (2019). Modular reconfiguration of an auditory control brain network supports adaptive listening behavior. Proceedings of the National Academy of Sciences, 116(2), 660-669.

Avenevoli, S., Baio, J., Bitsko, R. H., Blumberg, S. J., Brody, D. J., Crosby, A., Gfroerer, J., Ghandour, R. M., Hall, J. E., \& Hedden, S. L. (2013). Mental health surveillance among children-United States, 2005-2011.

Bautista, L. B. (2017). Duterte and his quixotic war on drugs.

Bodenmann, G., Meuwly, N., Bradbury, T. N., Gmelch, S., \& Ledermann, T. (2010). Stress, anger, and verbal aggression in intimate relationships: Moderating effects of individual and dyadic coping. Journal of Social and Personal Relationships, 27(3), 408-424.

Brammer, L. M., \& Karkia, P. (1993). The Helping Relationship: Process and Skills, trans. P. Karkia (1998). Tehran: Samt Press.

Cao, Z., Wei, F., Li, S., Li, W., Zhou, M., \& Wang, H. (2015). Learning summary prior representation for extractive summarization. Proceedings of the 53rd Annual Meeting of the Association for Computational Linguistics and the 7th International Joint Conference on Natural Language Processing (Volume 2: Short Papers), 829-833.

Coates, D., David, M., Roberts, B., \& Duerden, D. (2019). An examination of the profile and journey of patients with mental illness in the emergency department. International Emergency Nursing, 43, 15-22.

Cohen-Scali, V., Rossier, J., \& Nota, L. (2018). New perspectives on career counseling and guidance in Europe. Springer.

Corey, G. (2015). Theory and practice of counseling and psychotherapy. Nelson Education.

Cormier, S., Nurius, P. S., \& Osborn, C. J. (2008). Interviewing and Change Strategies for Helpers: Fundamental Skills and Cognitive Behavioral Interventions, 6th. Cengage Learning. 
Davidson, L., Bellamy, C., Guy, K., \& Miller, R. (2012). Peer support among persons with severe mental illnesses: A review of evidence and experience. World Psychiatry, 11(2), 123-128.

Elliott, R., Bohart, A. C., Watson, J. C., \& Murphy, D. (2018). Therapist empathy and client outcome: An updated meta-analysis. Psychotherapy, 55(4), 399.

Faggiano, F., Minozzi, S., Versino, E., \& Buscemi, D. (2014). Universal school-based prevention for illicit drug use. Cochrane Database of Systematic Reviews, 12.

Farber, B. A., \& Suzuki, J. Y. (2018). Affirming the case for positive regard.

Farber, B. A., Suzuki, J. Y., \& Lynch, D. A. (2018). Positive regard and psychotherapy outcome: A meta-analytic review. Psychotherapy, 55(4), 411.

Groeneveld, M. G., Vermeer, H. J., van IJzendoorn, M. H., \& Linting, M. (2010). Children's wellbeing and cortisol levels in home-based and center-based childcare. Early Childhood Research Quarterly, 25(4), 502-514.

Group, C. P. P. R. (2011). The effects of the Fast Track preventive intervention on the development of conduct disorder across childhood. Child Development, 82(1), 331-345.

Grove, M. E., White, S., Fisk, D. G., Rego, S., Dagan-Rosenfeld, O., Kohler, J. N., Reuter, C. M., Bonner, D., Network, U. D., \& Wheeler, M. T. (2019). Developing a genomics rotation: Practical training around variant interpretation for genetic counseling students. Journal of Genetic Counseling, 28(2), 466-476.

Hartanto, H. (2017). Validitas dan Reliabilitas Warwick-Edinburg Mental Well Being Scale. Counsellia: Jurnal Bimbingan Dan Konseling, 6(2), 1-16.

Hser, Y.-I., Lanza, H. I., Li, L., Kahn, E., Evans, E., \& Schulte, M. (2015). Maternal mental health and children's internalizing and externalizing behaviors: Beyond maternal substance use disorders. Journal of Child and Family Studies, 24(3), 638-648.

Jayne, K. M., Purswell, K. E., \& Stulmaker, H. L. (2019). Facilitating congruence, empathy, and unconditional positive regard through therapeutic limit-setting: Attitudinal conditions limit-setting model (ACLM). International Journal of Play Therapy, 28(4), 238.

Jonas, D. E., Garbutt, J. C., Brown, J. M., Amick, H. R., Brownley, K. A., Council, C. L., Viera, A. J., Wilkins, T. M., Schwartz, C. J., \& Richmond, E. M. (2012). Screening, behavioral counseling, and referral in primary care to reduce alcohol misuse.

Jonson-Reid, M., \& Chiang, C.-J. (2019). Problems in understanding program efficacy in child welfare. In Re-visioning public health approaches for protecting children (pp. 349-377). Springer.

Kristiyani, T. (2013). Keterlibatan Orangtua dalam Pendidikan dan Komitmen Siswa terhadap Sekolah: Studi Meta-analisis. Buletin Psikologi, 21(1), 31.

Lazarus, G., Bar-Kalifa, E., \& Rafaeli, E. (2018). Accurate where it counts: Empathic accuracy on conflict and no-conflict days. Emotion, 18(2), 212.

Lowe, D. J., Sasiadek, J. D., Coles, A. S., \& George, T. P. (2019). Cannabis and mental illness: A review. European Archives of Psychiatry and Clinical Neuroscience, 269(1), 107-120.

Mastroleo, N. R., Mallett, K. A., Ray, A. E., \& Turrisi, R. (2008). The process of delivering peer-based alcohol intervention programs in college settings. Journal of College Student Development, 49(3), 255.

Matz-Costa, C., Howard, E. P., Castaneda-Sceppa, C., Diaz-Valdes Iriarte, A., \& Lachman, M. E. (2019). Peer-based strategies to support physical activity 
interventions for older adults: A typology, conceptual framework, and practice guidelines. The Gerontologist, 59(6), 1007-1016.

Mawardah, M., \& Adiyanti, M. G. (2014). Regulasi emosi dan kelompok teman sebaya pelaku cyberbullying. Jurnal Psikologi, 41(1), 60-73.

Moyer, V. A. (2013). Screening and behavioral counseling interventions in primary care to reduce alcohol misuse: US preventive services task force recommendation statement. Annals of Internal Medicine, 159(3), 210-218.

Muller, C. (2018). Parent involvement and academic achievement: An analysis of family resources available to the child. In Parents, their children, and schools (pp. 77114). Routledge.

Nomura, Y., Hurd, Y. L., \& Pilowsky, D. J. (2012). Life-time risk for substance use among offspring of abusive family environment from the community. Substance Use \& Misuse, 47(12), 1281-1292.

Nurmalitasari, F. (2015). Perkembangan sosial emosi pada anak usia prasekolah. Buletin Psikologi, 23(2), 103-111.

Oluremi Fareo, D. (2012). Drug Abuse Among Nigerian Adolescents Strategies For Counselling. Journal of International Social Research, 5(20).

Parrot III, L. (2003). Counseling \& Psychotherapy. 2nd. Ed.

Pruett, M. K., Cowan, P. A., Cowan, C. P., Gillette, P., \& Pruett, K. D. (2019). Supporting father involvement: An intervention with community and child welfare-referred couples. Family Relations, 68(1), 51-67.

Robinson, A. (2019). Acculturation and Millennial Migration: A Cultural Congruence Framework. Canadian Journal of Counselling \& Psychotherapy/Revue Canadienne de Counseling et de Psychothérapie, 53(2).

Rowe, C. L. (2012). Family therapy for drug abuse: Review and updates 2003-2010. Journal of Marital and Family Therapy, 38(1), 59-81.

Sandler, I. N., Schoenfelder, E. N., Wolchik, S. A., \& MacKinnon, D. P. (2011). Longterm impact of prevention programs to promote effective parenting: Lasting effects but uncertain processes. Annual Review of Psychology, 62, 299-329.

Sektnan, M., McClelland, M. M., Acock, A., \& Morrison, F. J. (2010). Relations between early family risk, children's behavioral regulation, and academic achievement. Early Childhood Research Quarterly, 25(4), 464-479.

Sharf, R. S. (2015). Theories of psychotherapy \& counseling: Concepts and cases. Cengage Learning.

Sinadinovic, K., Berman, A. H., Hasson, D., \& Wennberg, P. (2010). Internet-based assessment and self-monitoring of problematic alcohol and drug use. Addictive Behaviors, 35(5), 464-470.

Slovák, P., Frauenberger, C., \& Fitzpatrick, G. (2017). Reflective practicum: A framework of sensitising concepts to design for transformative reflection. Proceedings of the 2017 CHI Conference on Human Factors in Computing Systems, 2696-2707.

Sommers-Flanagan, J., \& Sommers-Flanagan, R. (2018). Counseling and psychotherapy theories in context and practice: Skills, strategies, and techniques. John Wiley \& Sons.

Strom, B. L., \& Melmon, the late K. L. (2019). The use of pharmacoepidemiology to study beneficial drug effects. Pharmacoepidemiology, 813-836.

Strong, T., \& Zeman, D. (2010). Dialogic considerations of confrontation as a counseling activity: An examination of Allen Ivey's use of confronting as a microskill. Journal of Counseling \& Development, 88(3), 332-339. 
Subandi, M. A. (2014). Interaksi Dinamis Penderita Gangguan Psikotik dengan Keluarga. Buletin Psikologi, 22(2), 87-93.

Sugaya, L., Hasin, D. S., Olfson, M., Lin, K.-H., Grant, B. F., \& Blanco, C. (2012). Child physical abuse and adult mental health: A national study. Journal of Traumatic Stress, 25(4), 384-392.

Sumargi, A., \& Kristi, A. N. (2017). Well-Being Orang Tua, Pengasuhan Otoritatif, dan Perilaku Bermasalah pada Remaja. Jurnal Psikologi UGM, 44(3), 185-197.

Supriyanto, A. (2016a). Collaboration Counselor and Parent for Developing Student Spiritual Competency trough Comprehensive Guidance and Counseling Service. Jurnal Fokus Konseling, 2(1).

Supriyanto, A. (2016b). Kolaborasi Konselor, Guru, dan Orang Tua untuk Mengembangkankompetensi Anak Usia Dini Melalui Bimbingan Komprehensif. Jurnal CARE (Children Advisory Research and Education), 4(1), 1-8.

Trickett, P. K., Negriff, S., Ji, J., \& Peckins, M. (2011). Child maltreatment and adolescent development. Journal of Research on Adolescence, 21(1), 3-20.

Tzani-Pepelasi, C., Ioannou, M., Synnott, J., \& McDonnell, D. (2019). Peer support at schools: The Buddy Approach as a prevention and intervention strategy for school bullying. International Journal of Bullying Prevention, 1(2), 111-123.

Yu, M.-L., Brown, T., \& Thyer, L. (2019). The association between undergraduate occupational therapy students' listening and interpersonal skills and performance on practice education placements. Scandinavian Journal of Occupational Therapy, 26(4), 273-282.

Zhao, X., Chen, L., Guo, Z.-H., \& Liu, T. (2019). Predicting drug side effects with compact integration of heterogeneous networks. Current Bioinformatics, 14(8), 709-720. 